\title{
Kabul at War (1992-1996) : State, Ethnicity and Social Classes
}

\section{Gilles Dorronsoro}

\section{OpenEdition \\ Journals}

Electronic version

URL: http://journals.openedition.org/samaj/212

DOI: 10.4000/samaj.212

ISSN: 1960-6060

\section{Publisher}

Association pour la recherche sur l'Asie du Sud (ARAS)

\section{Electronic reference}

Gilles Dorronsoro, « Kabul at War (1992-1996) : State, Ethnicity and Social Classes », South Asia Multidisciplinary Academic Journal [Online], Free-Standing Articles, Online since 14 October 2007, connection on 30 April 2019. URL : http://journals.openedition.org/samaj/212 ; DOI : 10.4000/ samaj.212

\section{(C) $\Theta \Theta \Theta$}

This work is licensed under a Creative Commons Attribution-NonCommercial-NoDerivatives 4.0 International License. 


\title{
samaj South Asia Multidisciplinary Academic Journal
}

Dorronsoro, Gilles (2007) 'Kabul at War (1992-1996): State, Ethnicity and Social Classes', South Asia Multidisciplinary Academic Journal, URL : http://samaj.revues.org/document212.html. To quote a passage, use paragraph (§).

\section{Kabul at War (1992-1996): State, Ethnicity and Social Classes}

Gilles Dorronsoro

\begin{abstract}
Kabul witnessed especially violent fights during the 1992-95 period. This article explains how, after the destruction of the state in 1992 following the fall of the communist regime, the city became a theatre of conflict between various armed groups. Contrary to popular opinion, the conflict in Kabul was not the product of irrational ethnic cleavages but the unanticipated consequence of rational strategies. More specifically, the city became a metaphor for the state, a central economic stake, and a place where opposing social groups fought each other.
\end{abstract}


Dorronsoro, Gilles (2007) 'Kabul at War (1992-1996): State, Ethnicity and Social Classes', South Asia Multidisciplinary Academic Journal, URL : http://samaj.revues.org/document212.html. To quote a passage, use paragraph (§).

[1] This article focuses on the 1992-1996 period of the Afghan civil war. During these four crucial years, Kabul evolved as a small-scale, yet distorted, model of Afghanistan itself. Indeed, it was the place where the armed actors tried to define the country's future political system and where social and communal conflicts crystallized. The following pages attempt to grasp this process by analyzing the city as a spatial metaphor of the state, as a place wherein communal identities were redefined, as an economical gamble, and, finally, as the centre for the urban/rural confrontation'. First, though, I will examine how Kabul became the focus of fighting after the fall of the communist regime in 1992 and how the interplay of rational strategies produced the quasidestruction of the city.

\section{Kabul as a contested city}

[2] Although the war was mainly conducted in the countryside during the period between the communist coup of 1978 and the collapse of the Kabul regime in 1992, the Afghan government was also confronted with opposition from the urban population. As soon as March 1979, even before the Soviet invasion, the city of Herat revolted and was out of government control for an entire week. The repression that followed caused 10,000 to 20,000 deaths $^{2}$. After the Soviet invasion in December 1979, many cities experienced mutiny, merchant strikes and student protests. In Kabul, social groups mobilized against the regime, even if the omnipresence of the secret services and the prohibition of public gatherings rapidly limited the traditional sociability of the bazaar. During a student protest held by a girls' school in Zarghuna on the occasion of the second anniversary of the Communist coup, police shootings resulted in several student deaths. At night, the inhabitants of the bazaar screamed 'Allah o akbar' (God is great) and, by morning, walls were covered with shabname (tracts) against the government and graffiti. Clothing was also used as a mean to signify opposition to the government: the opponents used to wear the pakol, a Nuristani beret adopted by the resistance, notably by the famous Panjshirbased commander Masud.

\footnotetext{
${ }^{1}$ Actually, this article does not limit itself to the city Kabul only. The spatial scope varies according to the issues in question. Social aspects can be understood by focusing on the city strictly speaking. But the neighboring towns, such as Paghman and Shar Asyab, from which Kabul can be bombed, and the surrounding countryside have to be taken into account as far as military strategies and economic issues are concerned.

${ }^{2}$ For an account of the revolt, see Dorronsoro (2005: 93).
} 
Dorronsoro, Gilles (2007) 'Kabul at War (1992-1996): State, Ethnicity and Social Classes', South Asia Multidisciplinary Academic Journal, URL : http://samaj.revues.org/document212.html. To quote a passage, use paragraph (§).

[3] In the early years, the guerrilla - who, at the time, enjoyed popular support - easily penetrated most cities. From the very beginning, however, fighter groups were absent from Kabul, which had benefited from a strong police and military presence. Besides undertaking specific military operations and attacks in the bazaar, the essential activity of the resistance in the capital was to gather information. Bombardments were relatively limited since the Soviets progressively added security belts around the city after the mujahidin had acquired more effective rocket launchers. Apart from these limited changes, it is a largely intact city that the mujahidin entered and - for many - discovered in April $1992^{3}$. From 1992 to the arrival of the Taliban in September 1996, controlling the capital became the principal military and political objective of the military actors. Clashes happened therefore mostly in Kabul. Most provinces, on the other hand, experienced a significant decrease in military activity as hundreds of thousands of people had already gone into exile in Pakistan and Iran. In the peaceful regions, reconstruction began, particularly in Herat and Ghazni ${ }^{4}$. The bombings destroyed a large part of the western and southern districts of Kabul and most of the infrastructure, such as water and electrical installations, was seriously damaged. According to the International Committee of the Red Cross, the fighting caused 25,000 deaths in the capital. Moreover, the state of permanent insecurity linked to rocket fire prompted many people to leave the city. Out of a population estimated at 1.6 million in 1992, 500,000 people left the capital in the months following the fall of the city in April 1992.

[4] Why was there such an increase in violence? First of all, the war in Kabul was the result of a failed transition process. Contrary to popular belief, the Soviet withdrawal did not bring about the collapse of the Kabul regime, which resisted the pressure of the mujahidin by concentrating its forces in the cities. Yet, the coup against Gorbachev in August 1991, which led some months later to the collapse of the USSR, meant the end of the aid to the Afghan regime. Consequently, the Afghan regime no longer possessed the means to maintain its military apparatus. Expectations of negative outcomes led diverse actors within the regime to change their strategy and ally with the mujahidin. However, the UN's attempts to organise a peaceful transition were not successful as it did not take into account the complex relations between the

\footnotetext{
${ }^{3}$ In the perspective of their withdrawal, the Soviets had put Najibullah in place in 1986 to replace Karmal at the head of the pro-Soviet regime.

${ }^{4}$ Journalists especially describe the events that took place in Kabul, where they could easily work. In this way, they contributed to the construction of a problematic perception of the war. Abroad, these images were until then rare and suggested increasing violence in the civil war.
} 
Dorronsoro, Gilles (2007) 'Kabul at War (1992-1996): State, Ethnicity and Social Classes', South Asia Multidisciplinary Academic Journal, URL : http://samaj.revues.org/document212.html. To quote a passage, use paragraph (§).

different armed movements. Moreover, the UN and the Soviets tried to integrate the former king Zaher Shah, who was popular but did not have any military support, into the peace process. The fall of the regime was caused by the mutiny of Rashid Dostam's Northern militia, Jumbesh-i melli (National Front). Militias, initially formed by the government as part of its counter-insurrection policy, became an important component of the armed forces. Therefore, their defection was a mortal blow for the regime. As the mutiny spread out, the main mujahidin parties were able to come easily to the capital. They formed alliances with the remains of the state machinery (for example, the police and the secret service) and occupied ministries and districts, while building strategic and communitarian interests ${ }^{5}$.

[5] Circumstances united these parties, the Hezb-i wahdat (Abdul Ali Mazari), the Jamiat-I islami (Ahmad Shah Masud) and the Jumbesh (Rashid Dostam). Jumbesh won the race and seized the capital ${ }^{6}$. Dostam's forces - previously in charge of defending Kabul - were particularly efficient and managed to prevent the penetration of other movements in the city. Masud approached the city from his bases in the Northeast and took advantage of the fact that some governmental institutions joined forces with $\mathrm{him}^{7}$. He was also able to rely on relatively professional troops and, initially at least, on the support of the population. The third member of the alliance, the Hezb-i wahdat, came into existence, in 1990, as a fusion of different Shiite Hazara parties and benefited from the support of $\operatorname{~Iran~}^{8}$. It penetrated the districts located West of the city where many Shiite Hazaras lived.

[6] Three other parties were initially excluded from the city and positioned themselves with the opposition. First, the Ettehad, a fundamentalist party led by Sayyaf, established itself in the native region of its leader, in Paghman (West of Kabul), on the hills dominating the capital. Second, the Hezb-i islami had to retreat to the Southern suburbs, to Char Asyab, from where it threatened Kabul with its rockets. It did so after a failed attempt to settle in the city using its

\footnotetext{
${ }^{5}$ Interestingly, two actors, important at the national level, did not get involved in the conflict. First, Ismail Khan, the Governor of Herat, who was not only too far from the capital but also too busy in establishing his authority in the West. Plus, he belonged to the same party as Masud and their relations became more and more sour over the years. Second, Governor Haji Qadir in Jalalabad remained neutral. He headed a fragile coalition of commanders and was heavily implicated in the smuggling of contraband with Pakistan.

${ }^{6}$ It seems that contact between Masud and Rashid Dostum began in Autumn 1991.

${ }^{7}$ Following a meeting between Wakil, the minister for foreign affairs, and Masud, it was decided that the dignitaries of the regime would support the latter, partly out of fear of Hekmatyar.

8 The Hazaras are an ethnic group and live in the centre of Afghanistan. They constitute about 15 percent of the total population and mostly are Shiites, contrary to the majority of the population, which is Sunni.
} 
Dorronsoro, Gilles (2007) 'Kabul at War (1992-1996): State, Ethnicity and Social Classes', South Asia Multidisciplinary Academic Journal, URL : http://samaj.revues.org/document212.html. To quote a passage, use paragraph (§).

support within the armed forces and the police ${ }^{9}$. Finally, the Harakat-i enqelab, which was present in the East of the capital, had control of the road to Jalalabad. However, it did not attack the city directly and did not have a determinant role in the continuation of the conflict, possibly because of its internal divisions.

[7] While this was taking place, an agreement was signed in Peshawar, Pakistan, between the resistance parties on 24 April 1992. This agreement suggested the possibility of an interim government with a revolving President. Mojaddidi (the leader of Harakat-i enqelab) was appointed President for two months. Rabbani (the leader of Jamiat-i islami) took his place, in theory for four months, but his mandate was prolonged under conditions that other movements opposed. In addition, the post of prime minister was given to the Hezb-i islami, which had continuously bombed a city defended by Masud, now Rabbani's defense minister. This paradoxical situation reflects well the incoherence of a government unable to establish any recognized institution at a national level.

[8] For four years, these groups constantly changed alliances. Summer 1992 was marked by rocket fire from Hekmatyar and Sayyaf that brought the city into war. In November 1992, Masud broke his initial alliance with Hezb-i wahdat and joined the Ettehad before forming another alliance with Hezb-i wahdat a few months later. The second determinant rupture was in January 1994 when the Jumbesh rejoined the Hezb-i islami in the opposition. This provoked a period of extremely violent fighting.

[9] In the autumn of 1994, the emergence of the Taliban movement and its rapid progression radically changed the balance of power. First considered with sympathy by Masud, who correctly saw the movement as a mortal adversary to the Hezb-i islami, the Taliban soon posed a threat as its success brought it closer to Kabul. Because the Hezb-i islami was swept from the south of the capital in February 1995, the Hezb-i wahdat, its ally, found itself isolated and weakened and was soon eliminated ${ }^{10}$. Taking advantage of the situation, Masud took complete control of the city, but too late to resist the pressure of the Taliban. In September 1996, the Taliban launched an offensive against Jalalabad. The betrayal of several commanders had allowed them to take control over the city without even fighting. The Taliban also seized Kabul

\footnotetext{
${ }^{9}$ Hekmatyar attempted a coup in 1991, forming an alliance with part of the army. The purges that followed this attempt weakened groups associated with Hekmatyar, making it difficult for them to help him during the fall of the capital in 1992.

${ }^{10}$ Mazari, the leader of Hezb-i wahdat, would be imprisoned by the Taliban during an offensive afterwards. He died in unknown circumstances, though he was probably killed while trying to escape.
} 
Dorronsoro, Gilles (2007) 'Kabul at War (1992-1996): State, Ethnicity and Social Classes', South Asia Multidisciplinary Academic Journal, URL : http://samaj.revues.org/document212.html. To quote a passage, use paragraph (§).

without any fighting and Masud had to evacuate the city. The taking of Kabul by the Taliban was a major point of rupture in the war; the Taliban was able to progressively reconstruct a government. This lasted until 2001, until the US intervention, which would, in turn, provoke a new phase of fragmentation and civil war.

\section{Kabul as a metaphor of the state}

[10] In the view of many observers, the situation we have described was totally confused, even anarchical. Journalists, academics, and other analysts started to label and stigmatize the conflict as an 'ethnic war' thereby reducing it to an infra-political dynamic; the stereotypical thesis of a 'return to the state of nature' was, from now on, regularly applied to Afghanistan (Tarzi 1993). Actually, the way hostilities were evolving was, on the contrary, quite logical. Because the rationality of the political actors was essentially tactical, observers could not decipher it easily. In order to understand the violence, three aspects need to be recalled: a) the existing links between Kabul and the state, b) the kind of resources available in the city and, c) the strategic constraints the actors dealt with. I now turn to these three points.

[11] When the Afghan empire was founded in 1747, the tribal chief Ahmad Shah was elected as the amir of the Pasthun tribal confederation. In 1775, his successor, Timur, decided to transfer the capital from Qandahar to Kabul in order to reinforce the political centre's autonomy, which was contested by the southern tribes. Historically, therefore, the Afghan state was 'traditional', as Anthony Giddens would say: it was based on a 'city versus countryside' divide. The state apparatus did not penetrate the rural world but extracted its resources through negotiation or coercion. Consequently, class divisions in Afghanistan have, more so than in other social systems, a geographical dimension. This makes the city-countryside cleavage all the more significant (Giddens 1987$)^{11}$. From the late $19^{\text {th }}$ century onwards, the construction of the modern state was engineered from the capital, potentially rival powers were eliminated and modern institutions were set up following the western mode ${ }^{12}$. During the second half of the $20^{\text {th }}$ century, the state made its presence felt more strongly in the countryside and embarked on an authoritarian process of modernization.

\footnotetext{
${ }^{11}$ For a discussion of this concept in the Afghan case, see Rubin (1988).

12 Since the 1950s, the state's authority over Afghanistan's territory was almost uncontested. Yet, the administration remained badly underdeveloped.
} 
Dorronsoro, Gilles (2007) 'Kabul at War (1992-1996): State, Ethnicity and Social Classes', South Asia Multidisciplinary Academic Journal, URL : http://samaj.revues.org/document212.html. To quote a passage, use paragraph (§).

[12] The war stopped this centralization/modernization process and, as early as 1978, the countryside was out of control. This was aggravated by the fact that after the Soviet withdrawal, the Najibullah regime (1986-1992) granted more and more autonomy to local authorities. The centre's withdrawal was principally a consequence of its politics of counter-insurgency, which encouraged the formation of local militias. The state apparatus, progressively weakened, had no national coherency anymore; even less so because regional powers such as the northern militias started to appear. These powers were the origin of the 1992 Coup. The fall of the regime accelerated the formation of several political territories, and relatively stable ones generally formed around urban centres (Herat, Jalalabad, Mazar-i Sharif). But, because these regions were in harsh competition with one another, frontlines became political frontiers. Consequently, heading a ministry in Kabul did not mean more, in April 1992, than controlling its building.

[13] As a matter of fact, Kabul was even more atypical in this context that it was a politically 'empty' space. Contrary to what was happening in most of the other provinces wherein a regional power - a commander or a coalition of commanders - besieged a city, no power was able to dominate Kabul. As a result, the city, rather than being an actor, is a space, a stake in the confrontational game. At no point, during the four years of long hostilities, did a military or political power emerge that originated from the city itself ${ }^{13}$. This is an important point: it demonstrates that the violence is primarily imported. Then why was it so vital to control the capital?

[14] One of the most significant issues at stake in dominating the administrative centre was the financial and symbolic reward that grabbing the vestiges of the state provided, ie. diplomatic representation abroad and the power to issue currency. This explains why the Masudled opposition was so insistent on gaining international recognition. Controlling monetary production was not only a symbolic issue. Being able to pay the state's functionaries, and especially those who were posted in provinces, though on an irregular basis, helped maintain a semblance of relations between the centre and the periphery. How important the issue was can be gauged by the intense fights it provoked between the opposition parties. Cases in point are the Hizb-i Islami, which refused to use the new 5,000 Afghani note that the Rabbani government had

\footnotetext{
${ }^{13}$ Masud was initially based in the Panjshir, some few hours away from the capital by road. But his conflict with the Hizb-e Islami meant that he had to extend his political power towards the North. In addition, the military or police forces that were present in the capital were far from constituting autonomous actors as they usually joined one political party or the other.
} 
Dorronsoro, Gilles (2007) 'Kabul at War (1992-1996): State, Ethnicity and Social Classes', South Asia Multidisciplinary Academic Journal, URL : http://samaj.revues.org/document212.html. To quote a passage, use paragraph (§).

just issued in October 1994, and Dostam, who was getting his own notes printed in Uzbekistan ${ }^{14}$. This led to a classical situation of dual power.

[15] Ruling over Kabul was important as well because the city was perceived as the site from which a new political balance would soon emerge; this is, at least, what all the actors believed. Truly, the city still worked as the spatial metaphor of a unitary state in the mental perceptions of the political actors. In this regard, the proposal to partition Afghanistan regularly put forward by foreign analysts throughout the 1980s was quite irrelevant, even more so because preserving the boundaries of a state, notwithstanding the state's obvious failure, remains a strong principle of the international system. Similarly, to transform Kabul into the symbolic centre of a federation -- a dream nurtured by some parties at that time -- raised intractable problems: how could ethnic boundaries be delineated, and how could this occur without the capital being neutralized, ie. occupied and possibly on a communal basis? These questions will be developed later.

[16] Actually, the strategic situation of Kabul remained open and unsettled throughout the conflict. First, there was no agreement on how the city should be divided, even de facto; this was an important difference with Beirut, for instance. Second, and in the perspective of reforming the political system, occupying the urban space permitted new a political and institutional balance of power. Lastly, it has to be recalled that some actors, Masud, Hekmatyar and Sayyaf in particular, did not control any important urban centres ${ }^{15}$. Therefore, their political survival rested on the stranglehold they could manage to establish in the capital.

[17] What were the actors' objectives? This depended on the kind of constraints they faced. First, no single party was strong enough to assert its power on its own in Kabul; forming coalitions was unavoidable. Yet, it was also a highly volatile process as these alliances were based neither on trust nor on any long-term agreement. Any chance of compromise was ruled out by regional powers, which were constantly promoting confrontation rather than conciliation ${ }^{16}$, and,

\footnotetext{
${ }^{14}$ The Afghan government's currency was printed in Russia.

${ }^{15}$ Masud did have, nevertheless, an important sphere of influence in the north-east, while Dostam ruled several cities in the north. But Hekmatyar, unable to establish any local stronghold, was compelled to put all his bets on the capital. The situation of the Hezb-i wahdat was more complex because there are no Hazara-dominated cities in Afghanistan. There are only strong Hazara communities scattered in Mazar-i Sharif and Kabul. Controlling part of these two cities meant therefore, for the party, to have access to the financial resources the Hazarajat was lacking.

${ }^{16}$ Without going into greater details, it has to be recalled that each regional power supported a particular party in order to establish its influence in Afghanistan: Pakistan backed the Hezb-i islami, Iran the Hezb-i
} 
Dorronsoro, Gilles (2007) 'Kabul at War (1992-1996): State, Ethnicity and Social Classes', South Asia Multidisciplinary Academic Journal, URL : http://samaj.revues.org/document212.html. To quote a passage, use paragraph (§).

more importantly, by fundamental conflicts between the main players. Hezb-i islami and Jamiat could not collaborate, given the intensity of the tensions between them ${ }^{17}$. Similarly, the staunchly anti-Shia positions of the Saudi-sponsored Ettehad prevented any possibility of reconciliation with the Iran-supported Hezb-i wahdat. In fact, the destruction that most of the western part of Kabul suffered was precisely due to their infighting.

[18] Secondly, the parties had contradictory political projects. Hezb-i islami and Jamiat, though ideologically close - they both emanated from the same Islamic organization in the 1970s - fought with one another over the control of the capital and the following construction of a centralized Islamic (Sunni) state. Ettehad shared these objectives, but had a much more fundamentalist agenda. Hezb-i wahdat, which reunited the Hazara Shias, and Jumbesh, which promoted an ethno-nationalist Uzbek discourse (Dorronsoro 1996b), both tried to influence the future political balance in order to get the regional autonomy that the other parties refused. Dostam, for instance, wanted to be present in Kabul to compensate for the fact that his regional base was in the Uzbek-dominated north-west. This remoteness was geographical as well as political: Uzbeks had a very marginal representation in the Afghan political system. As for the Hezb-i wahdat, it attempted to make itself accepted as a full political partner but this was bound to fail due to the anti-Shia and anti-Hazara prejudice of the other parties.

[19] As a matter of fact, both Jumbesh and Hezb-i wahdat were ideologically aloof from the dominant norm. They contemplated the reconstruction of a new central power with suspicion, as Sunni Islamists or fundamentalists would necessarily dominate it, and they were proved right. This is why these two parties relentlessly tried to prevent any coalition from becoming strong enough to eliminate political rivals and recreate a central power. Their presence in the capital was, therefore, first motivated by the desire to fragment and neutralize the political centre through the occupation of parts of the city and prevention of the reconstruction of the state.

[20] These objectives - controlling the space and/or destabilizing the dominant coalition shaped the patterns of violence between 1992 and 1996. When the balance of power was rapidly changing, direct involvement was favored so as to obtain tangible territorial gains. But when the

wahdat, Saudi Arabia the Ettehad and Russia was leaning towards Masud. This not only led to instrumentalist relations of the part of these countries and their Afghan clients but also introduced an additional level of constraints as far as reaching an acceptable solution was concerned: the interests of Iran and Saudi Arabia were just as conflicted as those between Pakistan and Russia.

17 Hekmatyar and Masud had been on very bad terms since the mid 1970s. Hekmatyar accused Masud (then close to Rabbani), of betraying the movement in the failed 1975 Islamist coup. He tortured and eventually killed a friend of Masud, Jan Mohamad, and ordered Masud's arrest, see Davies (1996). 
Dorronsoro, Gilles (2007) 'Kabul at War (1992-1996): State, Ethnicity and Social Classes', South Asia Multidisciplinary Academic Journal, URL : http://samaj.revues.org/document212.html. To quote a passage, use paragraph (§).

objective was to prevent the installation and reinforcement of a government -- in other words, to foil any political normalization -- actors used rocket bombings. These were not supported by infantry offensives, something that clearly demonstrates that no military results were sought.

[21] For various reasons, each party failed to reach its objectives. The Hezb-i wahdat and Jumbesh, first, were unacceptable to the other movements and proved unable to neutralize the centre. They were defeated by the Masud-led coalition and then by the Taliban. The Hezb-i islami, secondly, was expelled from Kabul by Masud's troops and then brought to a halt at the southern gates of the city and soon marginalized. Indeed, it was easy for the other parties to instrumentalize it in order to pressure the Masud-led governmental coalition; precisely because of its opposition to the Jamiat, the Hizb could not represent a viable political alternative. The emergence of the Taleban and the end of Pakistan's support, after years of unfailing help, dealt the party its final blow and led to its elimination from the political game until 2001.

[22] As for Masud, his strategy of enlarging his audience and rebuilding the state could have actually succeeded. He ended his early alliance with the Jumbesh and the Hizb-i wahdat because it had been built on incompatible long-term objectives. Masud, unlike his allies, never sought to divide Afghanistan into ethno-political regions led by one party or the other, and he was looking for allies in a Pashtun region that had always been reluctant to support him. If it were not for the unexpected emergence of the Taliban, this reconfiguration might have been possible: Masud's progressive ascendancy over the capital had already put him in a good position to negotiate with the parties that were well-rooted in the southern Pashtun regions.

\section{The politicization of ethnic identities and its limits}

[23] In order to understand the extent and limits of the politicization of ethnic identities, it is first necessary to unravel two important factors: Kabul's dramatic demographic evolution and the nature of ethnic solidarities within the urban context.

[24] Kabul began to develop from the $18^{\text {th }}$ century onwards when it became the country's capital. Yet, the real demographic transformation occurred during the second half of the $20^{\text {th }}$ century. In 1965, 30 percent of the capital's inhabitants $(127,000$ out of 435,000$)$ were born outside of the city, with half of these migrants having arrived within the last five years. Two thirds came either from Kabul province or from one of the adjoining provinces, i.e. almost all migrants came from the south and the west - at that time, the Hindu Kush mountain range presented a 
Dorronsoro, Gilles (2007) 'Kabul at War (1992-1996): State, Ethnicity and Social Classes', South Asia Multidisciplinary Academic Journal, URL : http://samaj.revues.org/document212.html. To quote a passage, use paragraph (§).

real barrier (Balland 1976). The flow of migrants increased dramatically in the 1970s, and then during the 1980s war. The population rose from approximately 600,000 people in 1979 to 1.6 million in 1992. At that time, a large majority of the inhabitants of Kabul were new migrants, and a considerable proportion of the long-established Kabuli middle classes fled following the post-1992 fighting.

[25] How did this massive influx of migrants and the resulting changes in the living conditions impacted Kabuli identity and the nature of social solidarities in the urban landscape? In Afghanistan, individuals recognize or locate themselves within a series of identities, ranging from very general (e.g. belonging to the umma, the Muslim community) to the highly specific (the immediate family). Identity can be based on a similar geographical origin or membership in the same profession, religion, family, ethnic group, etc. Collective mobilization is rarely based on macro-ethnic identities but responds to more limited affiliations ${ }^{18}$. The Uzbeks of Kabul are a case in point. This very small population gradually divided on the basis of origin between the Uzbeks originally from Central Asia (mohajir) and those from Afghanistan (watani). Social mobility also influences identities: the Uzbeks for instance, already urban dwellers prior to their arrival in Kabul, were rapidly assimilated as Tajiks, whereas this was not true for the people from the countryside. These shared identities enabled individuals to cooperate and forge bonds of solidarity. The concept of qawm $^{19}$ precisely designates the types of identities that develop within a solidarity network.

[26] Kabul is simultaneously an ethnic melting pot and an area of cohabitation between different social groups. There is, surely, a Kabuli identity, which manifests itself linguistically through variations in spelling and pronunciation of Persian (Farsi) ${ }^{20}$ and more generally through a particular habitus. This exemplifies a wider phenomenon: the strength of local identities in Afghanistan. To be a 'Kabuli' often has a greater meaning than being a Pashtun or, even more

18 The main macro-ethnic groups generally identified in Afghanistan are Pashtuns, Tajiks, Hazaras, Uzbeks, Turkmens, Baluchs and Nuristanis. On the complexity of ethnic identities in the region, see JeanPierre Digard (1988). In urban areas, the term 'Tajik' refers to Persian language (Farsi) speakers, although they do not form a coherent social group, nor can they easily be collectively mobilized. The city of Herat has, equally, a very strong identity, which partially transcends ethnic identities.

19 Originally, this Arabic term designated a group of patrilineal descent, but today it signifies 'homeland'. The term also has a more extended usage in Afghanistan as it qualifies all groups of solidarity. The qawm tends to circumscribe a global system of exchange based on the model of the extended family, even when the real basis for affiliation is elsewhere (professional, partisan or confessional), see Centlivres and Centlivres-Demont (1988).

${ }^{20}$ After a few generations, the inhabitants of the capital tend to adopt Persian (Farsi) in preference to Pashto or Turkish dialects; this is notably so in the case of the Pashtun tribal aristocracy. 
Dorronsoro, Gilles (2007) 'Kabul at War (1992-1996): State, Ethnicity and Social Classes', South Asia Multidisciplinary Academic Journal, URL : http://samaj.revues.org/document212.html. To quote a passage, use paragraph (§).

so, a Tajik. Furthermore, this urban dwellers' identity fuses with others identities which may manifest themselves either through ethnic hierarchy, the unity in certain city districts or, occasionally, specific professional occupations. Thus the Hazaras, ranked at the bottom of the ethnic hierarchy, are very visible in the city districts of Morad Khani and Wazir Abad and, since the 1950s, have spread close to Ali Abad and Afshar ${ }^{21}$. Lastly, most of the illegal settler population in the mountainous regions are Hazaras. They are often bakers, water carriers and labourers, even though a Hazara middle class had emerged progressively in the 1970s.

[27] The acceleration of the emigration to Kabul in the 1960s led to the development of surrounding villages and above all, of illegal settlements, especially in the Sher Darwaza and Koh-i Asmayi mountains. They are not shantytowns, but solid constructions, quite similar to those known in Turkey as gecekondu. The government has chosen to ignore this situation for decades and the successive town councils have neither provided basic amenities to these zones nor prohibited their construction. The main daily challenge in these areas is to transport drinkable water, which consumes about 10 percent of the family income (Bechhoefer 1977). Yet, despite these inconveniences, these houses remain more compatible with the rural Afghan lifestyle than modern apartments, enabling the founding of semi-rural localities within the city.

[28] This influx of rural people therefore profoundly changed the configuration of the city's population. The migrant, initially anticipating a temporary stay, often settled close to city dwellers with whom he/she shared some kind of social link, based on kinship or other ties. The integration and socialization within the urban context was not, initially at least, an individualistic process but, rather, occurred through the bias of an existing social network. Hence, these strong rural-urban bonds may, for the recent settlers, prevent or impede the development of a Kabuli identity. During the war, these links between Kabul and the countryside were further maintained through the mobilization of extended family ties (enlarged family, clan). These links facilitated the exchange of services, especially when a member of the network was affiliated with the government and another with the resistance. These intersecting protection mechanisms enabled the mujahidin's families to remain within the cities, while practices such as spying or exchanging prisoners would be carried out within these networks (Roy 1986).

[29] While these solidarity networks construe a particularly complex reality, the Kabul regime attempted to simplify them by politicizing macro-ethnic affiliations in the 1980 s in order to

${ }^{21}$ The Shiite Kizilbashes are historically present in Chendawal, but this district has seen an increasing proportion of Hazaras (Fazelli 1983). 
Dorronsoro, Gilles (2007) 'Kabul at War (1992-1996): State, Ethnicity and Social Classes', South Asia Multidisciplinary Academic Journal, URL : http://samaj.revues.org/document212.html. To quote a passage, use paragraph (§).

assess its power and, above all, to prevent the Jihadist discourse from destroying the government's legitimacy. This policy was a failure, at least in the short term. Indeed, the resistance parties had not made these macro-ethnic groups the basis for their own mobilization and, besides, their religious discourse superseded ethno-nationalist claims. The only case for which this policy produced results was with the Hazaras. Their nationalist discourse, employed mostly by ulema educated in Iran, had been the best mobilising force amongst the Hazara population during the war. But even there, Kabul's policy did not directly incur spectacular changes for two reasons. First, creating a specific Hazara region might have obliged the government to reorganize the entire administration. Second, too many concessions to the Hazaras' demands could have further weakened the Afghan Communist Party, which was already divided between two factions, the Khalq - mostly recruiting amongst Pashto speakers and Parcham, composed of a majority of urban/Persian speakers. The most notable outcome of Kabul's policy was, indeed, to increase the visibility of Hazaras in political life - in the early 1980s, the Prime Minister Sultan Ali Keshmand was a Hazara - and especially within the administration, particularly in Kabul. This further antagonized the Khalqis, who were not only ethnically distinct from the Parchamis but also at the bottom of the social hierarchy. While Parchami were primarily upper-middle class Kabulis, often at the margins of the ruling class (Najibullah, for example, married a member of the royal clan), Khalqis were primarily educated country folk without social connections.

[30] The government's policy had indeed prepared the ground for the effective ethnicization of the war, in other words the politicization of ethnic/community identities that would appear in the $1990 \mathrm{~s}^{22}$. The divisions within the Afghan Communist Party resurfaced when Kabul fell, and served as a basis for the strengthening of groups. Most of the Parchamis joined the Jumbesh, which was secretly supported by followers of the former president Karmal, and warmly welcomed Masud. The Khalqis mostly integrated into the Hezb-i islami, with which they shared two common features: the same social trajectory and Pashto as a first language.

[31] Regarding the mujahidin, the legitimization of the war as a Jihad had lost its meaning, probably as soon as the Soviet army had pulled out. The clashes between parties were nurtured primarily by a non-religious logic. In order to mobilize support, some movements openly employed an ethnic discourse (Hezb-i wahdat, Jumbesh), while others did so implicitly (Hezb-i

\footnotetext{
${ }^{22}$ At that time, and for the first time, tensions between Uzbeks and Hazaras emerged in Mazar-i Sharif. For a more global description of this phenomena see Dorronsoro (2005: 257).
} 
Dorronsoro, Gilles (2007) 'Kabul at War (1992-1996): State, Ethnicity and Social Classes', South Asia Multidisciplinary Academic Journal, URL : http://samaj.revues.org/document212.html. To quote a passage, use paragraph (§).

islami and Ettehad in particular). In some cases, ethnic identities became a strong political marker: any Panjshiri was suspected of being pro-Masud and faced a real risk of being arrested, especially under the Taliban regime. Moreover, the parties were often rooted in the districts where they could hope to mobilize communitarian support.

[32] This phenomenon must, however, be put in its proper context, as the map of Kabul does not show a clear geographical division into ethno-political zones. First, social characteristics, much more often than ethnic identities, determined partisan affiliations. Second, some groups had only a military presence, such as the Jumbesh, which could not count on any significant Uzbek community in Kabul ${ }^{23}$. Third, political practices were generally functioning within the framework of a clientelism based on qawm solidarities. This was the standard way power operated in Afghanistan under the communists as well as under the Taliban. For instance, President Rabbani routinely promoted the Badakhshis (from the Badakhshan province where he was born) to positions of responsibility, while Masud knew he could count on the Panjshiris etc. Similarly, the support that Sayyaf enjoyed in Paghman was the product of clannish solidarities more than a call to Pashtun solidarity in general.

[33] The task of 'ethnicizing' the war undertaken by political parties had therefore only a limited impact, even more so if one recalls that national identity, probably strengthened during exile, remained the central reference point for individuals (Glatzer 1999). In one case, however, that of the Hazaras, ethnicization operated as a political project. In certain Western districts of the capital, the Hezb-i wahdat carried out, if not a real ethnic cleansing, at least brutal pressure to force the non-Hazaras to leave. Likewise, life became impossible for the Hazaras in the zones held by the Ettehad. Yet, the true degree of support for the Hezb-i wahdat among Kabul's Hazara population is difficult to appreciate. For instance, as the merchants were largely forbidden to trade with the Hazarajat, the war in Kabul often meant a significant loss of income. Their membership of the Hezb-i wahdat was probably as much the result of party pressure and of the discriminatory practices of other movements as it was a sincere expression of support for Hazara nationalism ${ }^{24}$. The Hezb-i wahdat's strategy led to a strong Sunni reaction and to the Afshar massacre. On 11

\footnotetext{
23 The Jumbesh are an interesting example because its militia and, especially, its leaders were far from being all Uzbeks, a concept that furthermore is not self-evident. The top-down construction of nationalism came into conflict here with insurmountable obstacles.

24 In general, the Hezb-i wahdat merged several revolutionary parties and had only a small following amongst the former Hazara elite, mostly eliminated during the internal conflicts in the Hazarajat during the 1980s (Sample 2000).
} 
Dorronsoro, Gilles (2007) 'Kabul at War (1992-1996): State, Ethnicity and Social Classes', South Asia Multidisciplinary Academic Journal, URL : http://samaj.revues.org/document212.html. To quote a passage, use paragraph (§).

February 1993, Sayyaf's and Masud's troops launched an attack against the Hezb-i wahdat, which lost control of Afshar, a district West of Kabul. For the next three days the victorious troops massacred numerous civilians (probably between 200 and 300). Witness statements confirmed that the mujahaddin entered homes and committed various atrocities (rapes, murders, body mutilation, etc.) (Gille 1993: 2). The massacre was the reaffirmation of ethnic hierarchies that the Hazaras had challenged by positioning themselves as political forces on the same footing as other groups. In Afghanistan, the coexistence between different communities had been possible because of the implicit recognition that a hierarchy, by definition unequal, existed. This is why ethnic cleansing, which is a specific type of violence that presupposes a will to eliminate another in order to seize a space, was quite rare.

\section{Economic stakes}

[34] The largest city in the country was bound to become an economic stake at a time when different groups were gathering resources to prepare their troops. The different battles in Kabul demonstrate that the nature of the war had changed because to take over a town required the costly build up of troops.

[35] The region of Kabul was in effect the first industrial centre of the country. It had a sufficient supply of electricity for industrial applications along the road leading to Jalalabad (Balland 1973), principally as a result of the three hydro-electric dams built on the river Kabul. The Jabal us-seraj textile factory, immediately north of Kabul, for instance, formed part of this relatively industrialised area $^{25}$. Along the road to Jalalabad, a burgeoning industrial zone had appeared with the concentration of an increased number of warehouses and small industries. Small industries were equally concentrated in the Kabul region, and as a result, so were the vast majority of workers. In addition, the southern regions, Logar province in particular, had important agricultural production that was easily sold due to its proximity to the capital. Karakul (sheep skins) for exportation and dried fruits were also processed in Kabul. Lastly, the city was an important communications centre since it is at the junction between the north and the south, on the one hand, and the eastern roads to Jalalabad and Pakistan, on the other. It thus provided a major platform for the exportation of Afghan products (rugs, karakul, etc.).

\footnotetext{
${ }^{25}$ For a presentation on the economy of the Kabul region, see Etienne (1972: 167).
} 
Dorronsoro, Gilles (2007) 'Kabul at War (1992-1996): State, Ethnicity and Social Classes', South Asia Multidisciplinary Academic Journal, URL : http://samaj.revues.org/document212.html. To quote a passage, use paragraph (§).

[36] By separating government-controlled urban zones from mujahidin-controlled rural zones, the Afghan war profoundly distorted the existing economic flows (Dorronsoro 1996a). The decreasing level of exchanges between the countryside and the cities was less the result of governmental or mujahidin forces' actions (they both allowed convoys in both directions to pass in exchange for bribes in some cases) than of the impossibility for men of military service age to go to the city (without risking conscription) and of people fleeing away from the countryside due to military operations. This decline in exchanges provoked a dramatic increase in prices. Moreover, the countryside was largely supplied by neighbouring countries (notably Pakistan), and this contributed to the creation of partially separate economic flows.

[37] In Kabul, the economic actors had to adapt themselves to the new conditions. Thus, blacksmiths no longer worked for the suburban peasant farmers, who could not come to the city. The Char Chata jewellers had to close their shops because they sold Turkmen jewellery that no longer arrived in the city from northern Afghanistan, and the demand for which had fallen due to the disappearance of tourists. This bazaar went over into selling hurricane lamps, very much in demand because of frequents power cuts (Delloye et al. 1986). Similarly, the goldsmiths vanished because of the difficulty in finding charcoal, while wood was more and more frequently replaced with fuel-oil, mainly in the bakeries. Elsewhere, the Soviet presence gave rise to a huge black market in arms, clothes and tools.

[38] In 1992, the fall of the regime narrowed the economic gap between towns and the countryside. Yet, it also generated a new economic regionalisation with urban hubs connected to neighbouring countries (Herat to Iran, Kandahar and Jalalabad to Pakistan, Mazar-i Sharif to Uzbekistan). With this new organization of the economy and with provincial towns being less dependent on the centre, Kabul lost its central position. For instance, the capital's airport - once the source of important profits drawn from the transport of products sold as contraband in Pakistan - was so regularly disrupted by the bombardments that Jalalabad airport became used more often ${ }^{26}$. Furthermore, contrary to the rest of the country, the city was subject to blockades, which prevented the free movement of goods between 1992 and 1996.

[39] In the absence of regular wage, the semi-professional troops of both sides lived on predation, mainly at checkpoints at the city limits where travellers were automatically taxed and sometimes mugged. The disorder led to the development of organised crime such as the looting 
Dorronsoro, Gilles (2007) 'Kabul at War (1992-1996): State, Ethnicity and Social Classes', South Asia Multidisciplinary Academic Journal, URL : http://samaj.revues.org/document212.html. To quote a passage, use paragraph (§).

of homes by armed gangs at night. When Kabul was captured, the sudden liberation of 4,000 prisoners, many imprisoned under common law, certainly did not contribute to improving security. In this troubled context, mercenaries drawn from Dostam's troops further 'distinguished' themselves by their ferocity, their frequent pillages, murders and rapes ${ }^{27}$. This daily and arbitrary violence explains why the inhabitants of Kabul overwhelmingly rejected the mujahidin, who were largely perceived as thieves.

[40] Additionally, frequent blockades aimed at emptying the city of its inhabitants. This tactic was particularly used by Hekmatyar (notably during winter 1994) because it helped controlling the access points to the south (towards Logar) and to the east (towards Pakistan), which were essential for the town's supply. A market, subsidized by the Hezb-i islami, existed in the south of the town (Char Asyab) in order to compete with the town's markets and to exploit the population's discontent. The Hezb-i islami regularly blockaded convoys (including those from the UN) destined for the capital and demanded that they be unloaded so they could be checked. How economically determinant this military tactic was can be gauged by the fact that when, in the beginning of 1995, the Hezb-i islami was expelled from the south of Kabul, the price of corn fell by half.

[41] A few exceptions aside, the armed groups did not seek to manage the economy but plundered or racketeered so as to satisfy their immediate requirements. Let us also clarify that, if sizeable individual profits were made, there were no economic intermediaries capable of exploiting the political parties or even of being intermediaries at an equal level. The bazaar, too disorganised, was not a social actor. As a matter of fact, the weakening of the individual merchants as a group and the disappearance of most industrial or semi-industrial production were the two major characteristics of the economic field during the four years of war. Only the NGOs organized, and in difficult conditions, some sort of economic assistance for the inhabitants, mainly during winter.

\section{The confrontation between the educated and the mujahidin}

[42] Contrary to what happened in Iran, where urban culture became dominant after the revolution (Hourcade 1988), the mujahidin entry into Kabul initiated a revenge against the previous years of modernization decided from the centre. In order to understand this social

\footnotetext{
${ }^{27}$ The militia that had formed the Jumbesh in 1992 was known throughout Afghanistan for its plundering.
} 
Dorronsoro, Gilles (2007) 'Kabul at War (1992-1996): State, Ethnicity and Social Classes', South Asia Multidisciplinary Academic Journal, URL : http://samaj.revues.org/document212.html. To quote a passage, use paragraph (§).

confrontation, which only hardened with the arrival of the Taliban, I will analyze the educated classes of Kabul, then the new legal system of the Taliban and their practices. Then some attention will be given to gender relationships as a mean of analyzing ideological and social opposition.

[43] Kabul is the heart of modernity/westernization in Afghanistan. Before the war, almost half of the urban population was concentrated in Kabul, which was the only real modern city. Herat has a very old urban culture, but remained traditional, as opposed to the capital, where modernity was apparent not only in urban organisation but also in the inhabitants' behaviour. The capital is the place where the Afghan elite was concentrated, living in the bourgeois areas of the capital. At least half of the upper echelons of the administration was Kabuli ${ }^{28}$. The Pashtun aristocracy, especially the royal clan of the Mohammadzai, which had played a central role in the constitution of the state, lived in Kabul and spoke Persian (Farsi) more than Pashto. In the 1960s, the proportion of Kabulis in the administrative elite once again increased (56 percent of the total). This occurred irrespective of ethnic group (77 percent of Tajiks working in the administrative elite were Kabuli; 71 percent of the Mohammadzai, 67 percent of Durranis and 40 percent of other Pashtuns). This reflected the growing importance of schooling in the capital. Indeed, the capital had an important concentration of educational structures: 20 percent of the pupils at the primary and secondary levels at the end of the 1960s, and 25 percent of the teaching body. Daud's policy (1973-1978) engendered a decrease in the number of Kabulis in the administrative elite because Daud wanted to open up the political and administrative system to those living in the provinces and, in particular, to the Pashtuns. Nevertheless, this transformation only affected the highest positions in the state hierarchy and did not undermine the domination of the capital by the elites.

[44] From the 1960s onwards, the majority of the educated in Kabul developed collective strategies within the first political parties. New practices appeared in the city, and this mainly affected the status of women. Urbanization per se was not a guarantee of greater autonomy for women. In fact, urban life often tends to economically marginalize the women and imposes the wearing of the chadri (or burqa) ${ }^{29}$ more often in unknown environments. Yet, amongst the Kabuli bourgeoisie, the schooling of girls went hand in hand with modern practices such as wearing

${ }^{28}$ During the 1928-1978 period the elite, according to Barnett Rubin's definition, includes governors, minister-judges of the Supreme Court, and heads of state (Rubin 1991).

${ }^{29} \mathrm{~A}$ garment that completely covers the outer body, the hair, and the face. It should be distinguished from the chador, which left the face exposed. 
Dorronsoro, Gilles (2007) 'Kabul at War (1992-1996): State, Ethnicity and Social Classes', South Asia Multidisciplinary Academic Journal, URL : http://samaj.revues.org/document212.html. To quote a passage, use paragraph (§).

western clothes, a very fashionable trend in the 1970s, but not looked on warmly by the traditionalists ${ }^{30}$.

[45] However, the city's modernity often ceased to exist a few hundred meters away from these areas. Women in chadri were still very much in the majority in the bazaar and the population maintained its traditional religious practices. Besides, the post-1960s exodus led to a rural influx into the capital. The population doubled in few years and its ethnic and social makeup profoundly changed. This phenomenon peaked in the 1980s with the arrival of refugees because of security problems and the economic situation. Several hundred thousand people moved to the city's hillsides (deprived of water, and sometimes of electricity), and the suburbs expanded considerably. These newcomers, when confronted with the city's life, often had a tendency to adopt even stricter behaviour ${ }^{31}$.

[46] The war led to a more visible differentiation between the different areas of the city and between social groups. In essence, with the war, the provincial towns became more conservative, either under the mujahidin's pressure or out of a spontaneous support to the Jihad, while Kabul persisted in its path towards westernization. In Kabul, the modern Mikrorayon area, populated by civil servants and members of the Communist party, was probably more westernized than the bourgeois areas of Shahr-i naw (New City). Yet, Shahr-i naw was where social practices changed the most. Some women went out without a veil; others wore knee-length Russian-style skirts. Many of them had a professional activity outside of home (administration, healthcare, etc.), partly due to the fact that men were often in the army and that many were widows, without any other incomes. Because the war drafted many young men (or forced them to desert), women accounted for 50 percent of the lower positions in the administration, and 55 percent of all students in Kabul were young girls (Centlivres-Demont 1988). Marriages - although still arranged by families - were celebrated with rock bands and easily available alcohol. Political mobilization remained limited; though 15 percent of the PDPA members were women, we can infer from individual cases that they joined principally because of family solidarity. Some women's organisations, mainly inspired by Anahita Ratebzad, were active under the Najibullah regime but they did not have any important activities outside Kabul.

30 The condition of women had been the source of governmental attention since the 1920s under Amanullah. However, there had never been a significant Afghan feminist movement.

${ }^{31}$ The Afghans in the refugee camps in Pakistan have the same type of behaviour, particularly the more stringent monitoring of women. 
Dorronsoro, Gilles (2007) 'Kabul at War (1992-1996): State, Ethnicity and Social Classes', South Asia Multidisciplinary Academic Journal, URL : http://samaj.revues.org/document212.html. To quote a passage, use paragraph (§).

[47] With the fall of Kabul in 1992, a radically different period started. Some city-dwellers were nostalgic about the Najibullah regime and openly say so. Indeed, the arrival of the mujahidin was perceived by the majority of the Kabulis as the end of the specific urban culture of the city, though some political actors, such as Masud and Hekmatyar, had been students at the Kabul University. They thus had a sense of urban culture and belonged to this portion of the educated class that had become politicized through the Islamic movement. Masud, moreover, remained popular amongst some of the educated, because he represented a form of Islamic modernity. Other movements, particularly Sayyaf's one, had a much more fundamentalist vision of political Islam. Be that as it may, all of the parties imposed a series of legal fundamentalist measures, most notably the shariatization of the law. In May 1992 the new authorities decided, for instance, that civil servant had to pray together everyday. Wearing a moustache (perceived as a sign of pro-communist feelings) or being clean-shaven could lead to arrest. In September 1992, the first in a long series of public execution of delinquents was carried out. ${ }^{32}$ Sayyaf succeeded in getting female television newscasters removed (on 28th July 1992) and managed to have the Afghan government declare that awarding official positions to women would be prohibited. Similarly, Afghan women were also forbidden from attending the International Women's Conference in Beijing.

[48] In addition to these new legal rules, everyday incidents between the population and the mujahidin readily showed the distance that separated them. Many mujahidin had not been able to enter the towns since the beginning of the war and were out of touch with the urban world. Furthermore, amongst the rural Pashtuns there was a feeling of mistrust, of contempt for the city and its special by-laws, and for the disappearance of the tribal identity as a result of urbanization (Anderson 1982). Often very young, they belonged to the poorest rural classes. What is seldom emphasized, but is equally indicative of the divergence between the social groups, is the distress of those Kabulis who sought refuge in the countryside, principally in the Logar (Abou Zahab 1993), where the women complained of the difficulty in adapting to a rural environment and, for example, to the requirement to wear the chadri3

[49] These changes did not equally impinge on all social groups. The educated were the most affected, not only economically but also socially by the undermining of their values. First, the

\footnotetext{
32 But contrary to what is suggested by Amnesty International (1992), the three that were hanged by Masud's troops were not communists, but alleged delinquents accused of rape and murder.

${ }^{33}$ I witnessed, in 1993, in the Badghis province, refugees from Kabul facing very similar difficulties.
} 
Dorronsoro, Gilles (2007) 'Kabul at War (1992-1996): State, Ethnicity and Social Classes', South Asia Multidisciplinary Academic Journal, URL : http://samaj.revues.org/document212.html. To quote a passage, use paragraph (§).

state's collapse placed them in a difficult situation, as most of them were civil servants. The absence of salary for months at a time made them virtually unemployed and NGOs could only employ a limited number of them. Second, the educated classes' ways of life, notably regarding the status of women, were severely weakened by the imposition of a rigorous social and legal order $^{34}$. In effect, the arrival of the mujahidin implied a redefinition of public space, a space from which women were now excluded, just as they had been from practically all public activities during the war on the mujahidin side. For the majority of the mujahidin, women had nothing to do in the public space. In rural societies, women rarely venture outside the village space except if accompanied by a male relative. Yet, freedom of movement and a feminine society (with the sharing of chores, etc), from which men are de facto excluded (Poulton 1979, Lindholm 1996), do exist. For many young country-dwellers, women who venture outside without even a simple Iranian chador are a priori prostitutes, though it seems that violence against women was surprisingly rare, given the wartime context (Duprée 1993).

[50] In practice, women working in the administration were subjected to different pressures that forced them to leave ${ }^{35}$. However, these measures were barely enforced in the Ministry of Education, where 70 percent of the workforce was comprised of women, and the veil was not even imposed during the first few months. Elsewhere, the mujahidin infiltrated the buildings of humanitarian organizations and other workplaces to impose an Islamic dress code on Afghan female employees, who were increasingly obliged to wear the chadri in public rather than the lighter chador ${ }^{36}$. Kabul therefore followed the practice of the majority of other towns, notably Herat and Kandahar $^{37}$. In addition, female education - rare for young girls older than eight years old - started to become a problem in some places. Eventually, the destruction of the majority of the infrastructure, the insecurity and the ideological orientation of the mujahidin led a growing

34 Though anecdotal, the very hostile way the mujahidin looked at flight attendants working for the Afghanistan national during an inauguration at the airport in 1992 exemplified the confrontation between the two worlds. The female flight attendants covered their hair but wore western dress.

35 The policy of the foreign secretary in 1992, more respectful of women's rights, seems to be an exception. In fact, this minister was not really representative of the mujahidin, because he was a rich merchant who had tried to reconcile the Kabul regime with the parties' heads during the transition phase.

36 'Alors qu'en avril j'avais visité des postes de premier secours tenus par des femmes médecins, je découvre des rues presque sans femmes; le tchador (foulard) ne suffit plus, il faut porter le tchadri (survêtement couvrant la femme de la tête aux pieds)' (When in April I visited the relief camps run by female doctors, I discovered streets almost without women; the chador (veil) was not sufficient, it was now necessary to wear the chadri (over-clothes covering the woman from head to toe) (Vontobel 1992).

${ }^{37}$ But in Herat, for instance, wearing the chadri never prevented a strong tradition of female education. Herat Girls' high school was one of the best in the country. After the arrival of the Taliban the education of girls had to be done in an informal manner. 
Dorronsoro, Gilles (2007) 'Kabul at War (1992-1996): State, Ethnicity and Social Classes', South Asia Multidisciplinary Academic Journal, URL : http://samaj.revues.org/document212.html. To quote a passage, use paragraph (§).

proportion of the educated to flee, as they often had the means to move abroad. Ultimately, those who remained were only those who, for economic or other reasons, could not leave.

\section{Conclusion}

[51] To conclude, I will underline the elements of continuity and rupture between the 1992-1996 situation and the one prevailing under the Taliban. During the 1992-1996 period, the fighting had a strong political yet instrumental rationality: how to survive the competition and accumulate resources. Non-combatants were completely excluded from the political game, ethnic mobilization became more relevant, and legitimizing the war in the name of Jihad was de facto abandoned. The main result was that the mujahidin, and perhaps politics itself, were radically discredited. There was a general demand for restoring order and ending the violence. This, of course, cleared the way for the Taliban, who at first responded to common aspirations ${ }^{38}$. Yet it would be simply fallacious to infer from this that either the emergence of the Taliban was inevitable or that the strategy of the actors in Kabul was irrational. Once their regional area had been cleared, the Taliban aimed, like all other parties, at taking the capital. Their success, brought by a complex interplay of different factors (Pakistani assistance, the attrition of other movements, etc.), marked a decisive and turning point in the civil war.

[52] In effect, the stabilization of the military situation in the capital after the arrival of the Taliban launched the reconstruction a political centre. This centralization and reconstruction process is often called into question for the simple reason that it did not lead to a return to the pre-war Afghan state structures. Here, the difference with the 1992-1996 period is very clear. The Taliban brought two important innovations. First, the state no longer enjoyed a privileged relationship with the educated class, which therefore, especially in Kabul, was largely excluded from political as well as administrative decisions. Within the new state, the ulema monopolized power to the detriment of the educated. Second, Kabul partially lost its role as a political centre. Mullah Omar, the amir al-mominin (Commander of Believers), did not live in Kabul but in Kandahar. Kabul was thus more an administrative than a political capital.

\footnotetext{
${ }^{38}$ The situation was different from that in Kandahar where instead of a political confrontation, the fighting was between small groups of racketeers. The outcome, however was the same: an exasperated population with aspirations for the return of order. Without Pakistani support, it is, however, highly unlikely that the Taliban movement would have been able to achieve such a military penetration of the south and to take Kabul.
} 
Dorronsoro, Gilles (2007) 'Kabul at War (1992-1996): State, Ethnicity and Social Classes', South Asia Multidisciplinary Academic Journal, URL : http://samaj.revues.org/document212.html. To quote a passage, use paragraph (§).

[53] Is the ethnic dimension the key to explain the Taliban's policy in the capital? The 1992-1996 phase shows, in fact, that frictions arose from the arrival of the mujahidin in the cities. The main conflict was between rural and urban dwellers, much more than between Pashtuns and other ethnic groups, even if the Pashtun's puritanism made them particularly aware of the gap between their values and those of the Kabuli urban women. The tide of fundamentalism, powerful from the beginning of the Jihad, was not only present in Pashtun regions, and the educated were not always unsympathetic to it. It is therefore necessary to contextualize the common idea that the Taliban marked a total rupture. What they introduced was, as a matter of fact, partly started in 1992 but went almost unnoticed because attention was focused on politico-military questions. 
Dorronsoro, Gilles (2007) 'Kabul at War (1992-1996): State, Ethnicity and Social Classes', South Asia Multidisciplinary Academic Journal, URL : http://samaj.revues.org/document212.html. To quote a passage, use paragraph (§).

\section{References}

Abou Zahab, Mariam (1993) 'Nouvel exode au Logar', Les Nouvelles d'Afghanistan, n 58-59.

Adamec, Ludwig W. (1987) A Biographical Dictionary of Contemporary Afghanistan, Graz: Akademische Druck und Verlagsanstalt.

Amnesty International (1992) Index ASA 11/02/92, September.

Anderson, Jon W. (1982) 'Social Structure and the Veil: Comportment and Composition of Interaction in Afghanistan', Anthropos, $n^{\circ} 77$.

Aziz, Abdullah (1987) Essai sur les catégories dirigeantes de l'Afghanistan 1945-1963, Berne, Francfort-am Main, New York - Paris: Peter Lang.

Balland, Daniel (1973) 'Une nouvelle génération d'industries en Afghanistan', Bulletin de la société languedocienne de Géographie, tome 7, fasc. 1.

Balland, Daniel (1976) 'L'immigration des ethnies turques à Kabul', in Aktuelle Probleme der Regionlatentwicklung und Stadtgeographie Afghanistans, Verlag Anton Hain.

Bechhoeffer, William B. (1977) 'The Role of Squatter Housing in the Urbanization of Kabul', Afghanistan Journal, $\mathrm{n}^{\circ} 1$.

Canfield, Robert L. (1972) Hazara Integration into the Afghan Nation: Some Changing Relations between the Hazaras and the Afghans Officials, New York: Asian Society, Occasional Paper n`3.

Canfield, Robert L.; Saharani M. N. (eds.) (1984) Revolutions and Rebellions in Afghanistan, Berkeley: University of California Press.

Centlivres, Pierre (1985) Paysannerie et pouvoir en Afghanistan: de la fin de la monarchie à l'intervention soviétique (Occasional Papers), Genève: Institut universitaire des hautes études internationales.

Centlivres, Pierre (1988) 'Les trois pôles de l'identité afghane au Pakistan', L'Homme, 8/4 (108).

Centlivres, Pierre; Centlivres-Demont, Micheline (1988) Et si l'on parlait de l'Afghanistan?, Neuchâtel: Ed. de l'Institut d'ethnologie \& Paris: Ed. de la Maison des sciences de l'homme.

Centlivres-Demont, Micheline (1988) 'Les femmes afghanes aujourd'hui', Afghanistan Info, $\mathrm{n}^{\circ} 23$, novembre.

Davies, Anthony (1996) 'A brotherly vendetta', Asiaweek, December 6.

Delloye, Emmanuel; Raonaq, Mohammad Ali; Velter, André (1986) 'Bazars l'état des lieux. Kabul (Afghanistan)' in Villes en guerre, Paris: Autrement, $n^{\circ} 86$, pp. 76-84.

Digard, Jean-Pierre (dir.) (1988) Le fait ethnique en Iran et en Afghanistan, Paris: Ed. du CNRS.

Dorronsoro, Gilles (1993) 'L'aide humanitaire en Afghanistan', Cultures et Conflits, Fall.

Dorronsoro, Gilles (1994) 'La politique de pacification en Afghanistan', in Gérard Chaliand (ed.), Stratégies de la guérilla, Paris: Payot.

Dorronsoro, Gilles (1994) 'Politique et ethnicité : les Tâdjiks d'Afghanistan', Revue du CEMOTI 18. 
Dorronsoro, Gilles (2007) 'Kabul at War (1992-1996): State, Ethnicity and Social Classes', South Asia Multidisciplinary Academic Journal, URL : http://samaj.revues.org/document212.html. To quote a passage, use paragraph (§).

Dorronsoro, Gilles (1996a) 'Afghanistan : des réseaux de solidarité aux espaces régionaux', in François Jean \& Jean-Christophe Rufin (dir.), Economie des guerres, civiles, Paris: Hachette.

Dorronsoro, Gilles (1996b) 'La construction d'un nationalisme turc en Afghanistan', La Lettre d'Asie centrale, 2.

Dorronsoro, Gilles (2005) Revolution Unending. Afghanistan: 1979 to the Present, Hurst \& Columbia University Press.

Duprée, Nancy Hatch (1993) 'Afghan women view of the future', Afghanistan Info, n³3, April.

Etienne, Gilbert (1972) L'Afghanistan ou les aléas de la coopération, Paris: PUF.

Fazelli, Mohammad (1983) 'L’islam chiite en Afghanistan', Les Nouvelles d'Afghanistan, n¹2-13, March, p. 19.

Giddens, Anthony (1987) The Nation-State and Violence, Volume Two of a contemporary Critique of Historical Materialism, University of California Press.

Gille, Etienne (1993) 'Crimes à Afchâr', Les nouvelles d'Afghanistan, n60.

Glatzer, Bernt (1999) 'Ethnizitaet im Afghanistankonflikt', Afghanistan Info , n45, September.

Hourcade, Bernard (1988) 'Ethnie, nation et citadinité en Iran', in Jean-Pierre Digard, Le fait ethnique en Iran et en Afghanistan, Paris: Editions du CNRS.

Lindholm, Cherry (1996) 'The Swat Pukhtun Family as a Political Training Ground' in Charles Lindholm, Frontier Perspectives, Oxford: Oxford University Press.

Poulton, Michelle (1979) 'La société des femmes dans un village afghan', Communautés 79, January-March, pp. 94-101.

Roy, Olivier (1986) 'Kabul', in Villes en guerre, Autrement, $n^{\circ} 86$.

Rubin, Barnett (1988) 'Lineage of the State in Afghanistan', Asian Survey, 28 (11).

Rubin, Barnett (1991) 'The Old Regime in Afghanistan: Recruitment and Training of a State Elite', Central Afghan Survey, 10 (3).

Rubin, Barnett (1992) 'Political Elites in Afghanistan: Rentier State Building, Rentier State Wrecking', International Journal of Middle East Studies, 24.

Sample, Michael (2000) 'Rural-urban Economic Linkages, Migration and the War Economy, A note on Hazara Business men in Kabul and Mazar', Afghanistan Info, $n^{\circ} 46$, March.

Tarzi, Mohammad (1993) 'Afghanistan 1992: An Hobbesian State of Nature', Asian Survey, 33 (2).

Vontobel, Catherine (1992) 'Deux retours à Kabul : avril et mai 1992', Afghanistan Info, October, $n^{\circ} 32$. 